\title{
Chinese Incursion and Impact in Africa
}

\author{
Dr. Okeke V. O. S. \\ Department of Political Science, Faculty of Social Sciences \\ Anambra State University, Igbariam, Anambra State University
}

\section{Doi:10.5901/ajis.2014.v3n1p283}

\begin{abstract}
Ever since the mid-1950s and 1980s, China has expanded its relations with Africa as part of its broader incursion and strategy of developing friendly relations with the "Third World Africa." In recent years, China has achieved deeper ties with many African countries, and the issue of impact in Africa has received more attention. China has enjoyed a long relationship with Africa, which became more intense in post-Mao era as the policy of non-interference in the internal affairs of African states or to respect the sovereignty of African states endures. These relations cover the vast areas of trade, investment, diplomacy, foreign policy, economy, agriculture, education, health, transport, infrastructure, tourism, security, defence, military, oil and gas. We demonstrated that Chinese new interest in Africa was primarily in area of securing strategic and important natural resources like crude oil. Not surprisingly, the impact of Chinese incursion into Africa has not improved Africa's economy significantly. This study is essentially qualitative and historical, and as such relies on secondary sources of data.
\end{abstract}

\section{Introduction}

China is fast becoming a developmental 'champion' and a beacon of hope for the world's poorest countries, many of which are to be found on the African continent. In the process it is fundamentally challenging the way in which the development of poor countries is considered; to the point where it is no longer axiomatic that the creation of a political democracy is an absolute requirement for economic and social progress. At the end of the Cold War it seemed that Western ideologies had won the day and it was generally accepted that there was a causal and symbiotic relationship between the establishment of a democratic political system and sustained developmental progress. China has now challenged that construct by promoting its own unique model of authoritarian centralized rule and the gradual adoption of market principles but with the preservation of many large state-controlled enterprises. For a number of differing reasons of self interest the leaders of many developing African countries find this model attractive. They now seem to argue that their countries should reject the failed Western system with all of its demanding conditions and follow the freer Chinese developmental model, pursuing economic growth first and deferring the political reforms until later. This change of approach is beginning to undermine the West's developmental efforts in Africa. For example, the International Monetary Fund (IMF) spent years negotiating a transparency agreement with the Angolan government only to be told in 2007 that Luanda was no longer interested in IMF money. Instead they had secured a \$2billion 'no conditions' loan from China. This scenario has been repeated across Africa in countries such as Chad, Ethiopia, Nigeria, Sudan and Zimbabwe. In its foreign policy pronouncements China has repeatedly reaffirmed its strong advocacy for the 'sovereignty' concept and the right of all states to be free of interference in their internal affairs. This is a position in direct contrast to the West's growing consensus for the justification of humanitarian intervention. For instance, China's trade with Kenya was around \$706 millions in 2007 and with China to fall back on President Kibaki could maintain his position even in the face of impending economic sanctions from the West. This delayed, and ultimately undermined, UN-led negotiations for a compromise agreement (Sidoli, 2009).

Beijing is prepared to offer aid and developmental funding to African states with 'no strings attached'. By contrast Western donors continue to tie their aid to demands for political reform and the protection of human rights. The Chinese are avowedly non-judgmental about the political and humanitarian behaviour of the countries with which they choose to deal. However, there appears to be limits to these 'no interference' and 'no strings attached' policies and Beijing is now seemingly prepared to apply some subtle pressure to its African 'partner' states to avoid criticism from the international community. At the centre of international pressure concerning the Darfur situation in the Sudan, Beijing was encouraged to use its political leverage on the Sudanese leadership to better manage a conflict that has reportedly seen the death of 400,000 people and the displacement of two millions. There is little doubt that China could exert considerable influence in this instance as it sells Sudan weapons, buys two thirds of its oil and has invested $\$ 6$ billion in its industries. 


\section{An Overview of China's Penetration in Africa}

In 2007 China's President Hu Jintao announced the creation of a new 'special economic zone' not on mainland China, but in the copper mining region of Zambia. A combination of export subsidies, tax breaks and investment in roads, railways and shipping would be extended across this zone. The Zambian leader, President Mwanawasa, was obviously delighted with the injection of an estimated $\$ 800$ million into his economy, announcing this would prove to be a transformational event in the development of his country. The Zambian 'special economic zone' was the first of five that the Chinese are intending to establish on the African continent. The second zone will be in Mauritius and will look to provide Chinese businesses with preferential access to the twenty African states that make up the Common Market of East and South Africa. The third zone will be a transportation hub, probably in the port of Dar es Salaam in Tanzania (Sidoli, 2009). Over the years China's engagement with the African continent has gone through a number of distinct phases, ranging from periods of intense activity to periods of relative neglect. Almost immediately after the inauguration of the People's Republic of China in October 1949 the Communist regime sought to restore China's historical international position through an increasing involvement with various African states but this aspiration was tempered by China's own internal political and economic developmental challenges. These early and limited, African excursions were very much undertaken under the guidance of Stalin's Soviet Union but as Mao

Tse-Tung's relationship with the Soviet Union deteriorated; China developed its own 'three worlds' policy, ostensibly acting as the non-aligned 'champion' of the developing world. This was the first example of China using Africa as a terrain for ideological competition (Large, 2007; Sidoli, 2009). At the Bandung conference in 1955, Mao's charismatic envoy, Chou En-Lai, wooed the African countries present promising China's 'solidarity' in their struggle for independence from their colonial masters. The level of concrete support to African nations that actually materialized was relatively limited but the low key contribution of the 'barefoot doctors' and a variety of Chinese agricultural specialists left a positive impression on the future leaders of a number of nascent African countries. Yet very much as today, there had to be some tangible benefit from this relationship for the Chinese. In this instance Mao used the goodwill of African nations (with their numerical presence and block-vote tendencies) to further his main foreign policy objective of removing the Republic of China from the coveted position as a member of the UN Security Council (Sidoli, 2009). The onset of the Cultural Revolution in 1968 saw the emergence of a more introspective China and as part of its self-imposed isolation, many Chinese projects with African 'comrades' were curtailed. A notable exception was the construction of the TanZam railway in 1975, linking Zambia with the port of Dar es Salaam (thereby freeing President Kaunda's Zambia from dependence on Rhodesia). It is interesting to note that many of the characteristics of that impressive project still resonate in China's relationship with Africa today, namely, the use of high profile 'signature' projects to cement relationships, a responsiveness to the personal requests of the African elites, the use of state sponsorship in large 'loss leader' infrastructure construction projects and a near total reliance on imported Chinese labour (Large, 2007; Sidoli, 2009). In the 1980s Mao's 'internationalist' strategies began to lose ground to the more immediate quest for China's internal modernization as advocated by the new and more pragmatic leader, Deng Xiaoping. Deng set China off on an internally focused path of gradual capitalist-orientated development, the so-called 'Yellow River Capitalism', that was largely responsible for producing the phenomenal levels of economic growth witnessed in China over recent years. During this same period Africa was experiencing ever greater social and economic challenges (which may well have been another exacerbating factor in China's temporary withdrawal from the African scene). The ending of the Cold War left many African leaders looking for alternative sources of political, diplomatic and military support to the Soviet Union. The loss of one of their primary sponsors had created a void that African leaders desperately needed to fill (Sidoli, 2009). In 1989, the Chinese leadership was taken aback by the action of its own people in the events around Tiananmen Square and also greatly angered by the Western world's reaction. It prompted an intense debate within the Communist Party hierarchy as to which direction the country should take. Deng Xiaoping's faction eventually prevailed, resulting in a recommitment to the existing quasi-capitalist model for the transformation of China's economy. As part of this period of post-Tiananmen reflection there was also reaffirmation of a foreign policy which was well encapsulated in Deng's subsequent statement: 'China needs to observe calmly, secure our position. Hide our capabilities and bide our time. Be good at maintaining a low profile, do not interfere, and never claim leadership (Large, 2007; Sidoli, 2009).

Nevertheless, the events of Tiananmen Square left China looking for new allies in the world. In a climate of nearuniversal condemnation, a number of African leaders grasped the opportunity to rekindle their relationship with China. Leaders from both Angola and Namibia (themselves with less than perfect credentials in terms of democratisation and human rights) used this occasion to show their solidarity with China, publicly congratulating the Chinese Army on their actions in quelling the 'rebellion'. At the same time China's ruling Communist elite had realised that their very survival 
depended on ensuring continued high levels of economic growth. Just as Deng exulted 'to get rich is glorious', the Chinese leadership began to appreciate that China's self-sufficiency in a host of vital areas such as energy, strategic minerals and forestry resources could no longer be maintained (Sidoli, 2009). Even its Diaqing oilfields, which Mao had made a byword for China's industrial zeal were now running dry. This series of interlinked events resulted in a renewed interest in the African continent, building on the firm foundations China had established in earlier years. The African elites in turn, remembering a China that had been a staunch supporter in the struggle for independence from colonial influence and against the domination of the Cold War superpowers, welcomed them back with open arms and set the conditions for the relationship that exists today. At this early stage of renewal it would seem that China's interests in Africa were purely driven by economic considerations, it being such a rich source of all the commodities that they desperately desired. This cynical, commercially-driven approach perpetuated one of the consistent features of Chinese engagement in Africa in that it has shown little discrimination in its choice of friends. As a direct consequence some of China's more long term partners in Africa are leaders of so-called 'pariah' regimes, as labeled by the international community. One prominent, and topical, example is in Zimbabwe, where the Chinese government supported the ZANU-PF movement in its struggle against white rule in Rhodesia. It then provided President Mugabe with decades of political, military and technical support in a relationship that continues to the present day, irrespective of a huge weight of condemnation from the international community (Large, 2007; Sidoli, 2009).

\section{China in Africa Today}

For the past two decades, China concentrated on curbing the military and diplomatic influence of Taiwan; the focus on "economization" of its Africa policy only began in the late 1990s. A measure of the importance with which Africa is held in China is that senior Chinese officials have established the diplomatic precedent of beginning each year with a major official visit to Africa. In 2007 the Foreign Minister, Li Zhaoxing, undertook a seven nation tour of Africa. The year before President Hu Jintao and Premier Wen Jiabao undertook an extended visit to more than a dozen African nations. This last round of visits was preceded by the issue of the first ever Chinese white paper on Sino-African relations, timed for the 50th anniversary of the start of China's diplomatic relationship with Africa (Sidoli, 2009).

At these meetings the Chinese leaders have routinely emphasised their commonality with Africa and their desire to support economic transformation whilst not interfering with the internal affairs of the African states. In a rather formulaic manner, they reiterate a desire for closer dialogue and cooperation in areas such as peacekeeping missions, medicine and health, and business partnerships. Beyond the rhetoric of these numerous bilateral meetings it is the three Forums on China-Africa Cooperation (FOCAC) summits that have actually provided the framework for Chinese expansion in Africa. The most recent summit (Beijing 2006) was by far the most impressive in its ambition. It is apparent that the Chinese leadership expended considerable effort in ensuring a successful outcome and, by all accounts, the African leaders enthusiastically embraced the vision set out in the FOCAC Beijing Action Plan. The Action Plan set out a target based plan for greater cooperation in several major policy areas, namely political and economic cooperation, cooperation in international affairs, and cooperation in social development (Taylor, 1998; Large, 2007; Sidoli, 2009). -More specifically, the Action Plan committed China to a development fund of \$5billion to be made available to support reputable Chinese companies investing in Africa. As an integral part of this plan China up-rated its direct aid to Africa by agreeing to cancel all existing loans due by end of 2005, both to heavily indebted poor countries and to those least developed countries that had strong diplomatic ties with China. This was the only condition that China applied to the loan cancellation initiative. The FOCAC Action Plan should be put into the backdrop of the considerable investment that China has already provided to African states. According to the World Bank53 Beijing's Export-Import Bank has provided a total of $\$ 800$ million in concessional loans for 55 projects in two dozen African countries. The World Bank study further estimates that as of the end of 2006 the total amount of Export-Import Bank (ExIm) loans is $\$ 12.5$ billion, mainly concentrated in Angola, Mozambique, Nigeria, Sudan and Zimbabwe (Taylor, 1998; Sidoli, 2009). Of course there are many hard commercial interests at play amidst all this largesse. China's energy needs continue to rise and oil imports from Africa account for $30 \%$ of China's total external oil dependence. China's stated intent of 'developing and rationally exploiting Africa's natural resources' is based on the knowledge that Africa has about $8 \%$ of the world's proven oil reserves. Since 2003 Angola has been the leading African supplier to China. Indeed in 2006 it accounted for over 50\% of China's oil imports, becoming China's biggest external supplier. New off-shore discoveries in the Gulf of Guinea are expected to provide one in every four new barrels that enter the marketplace over the next few years. Chinese oil companies are competing successfully with their Western counterparts to secure extraction rights, and to construct pipelines and refineries in this region (Large, 2007; Sidoli, 2009). Indeed, a recurring pattern emerges once these 
impressive 'partnership' arrangements have been agreed in concept at the multilateral level and in detail at the bilateral level. China's state-controlled commodities companies move in and secure access to valuable resources that before had been under the influence of Western conglomerates. Riding on the wave of diplomatic goodwill their speed of penetration of the resource market is nothing short of remarkable. On the back of this resource exploitation are a number of Chinese construction companies who, through their initial objective of facilitating access for resource extraction, have then broadened their exposure in the African construction market by successfully competing for a range of civil projects, such as hospitals, schools and sporting stadia (Taylor, 1998; Sidoli, 2009). Beijing's activist industrial strategy uses public money with some foreign private investment to build large capital-intensive industries across Africa. This would appear to have impressed their African partners to the point where they are reversing some of their economic policies, especially the privatization programmes demanded by the World Bank in the 1990s. Like China they are beginning to believe that the large state owned enterprises can produce transformational public profits which can be used in the national interest. Rather more cynically, the ruling elites in Africa also probably appreciate that by retaining control of these enterprises they can prevent politically motivated entrepreneurs from challenging their position (Sidoli, 2009). The remarkable rise in commodity prices in recent years has further empowering the leaders of resource rich African nations, and the election of independent-minded populist leaders has probably hardened their anti-Western stance. Ultimately, however, it is the stunning success of China's economy that has been the major attraction for African leaders. It is important to acknowledge that the Chinese penetration of African states is not all conducted in economic and commercial areas, but has additional educational aspects. China announced a commitment to make available 100 agricultural experts to set up demonstration sites and send 300 volunteers under the Chinese Young Volunteers Serving Africa programme to support education and sports related subjects. On the broader educational front China has undertaken to train 15,000 African professionals in the next three years, build 100 rural schools and double the number of scholarships available for African students in Chinese universities. Beijing has also sought to expand educational partnerships with Africa universities by creating three Confucius Institutes in Kenya, Rwanda and South Africa (Large, 2007; Sidoli, 2009). Another almost unnoticed aspect amidst all this high-level penetration is that many African nations are experiencing a wave of unprecedented immigration by individual Chinese citizens. Their reputation as hard-working, small scale entrepreneurs is manifest across the African continent as settlers set up corner stores, restaurants and laundry businesses. Exporting Chinese workers to Africa to work in both large and small scale enterprises may be a solution to one of China's key economic challenges that of rising unemployment at home. Finally, it is worth commenting that with its increasing personal wealth China is set to become one of the world's largest outbound tourist markets with a projection of 100 million Chinese travellers by 2020. In 2005 only 110,000 Chinese tourists visited Africa66 but China has now actively promoted Africa as a tourist destination, with two dozen African states designated as official tourist destinations (Taylor, 1998; Sidoli, 2009).

\section{China's Defence and Security Policy on Africa}

There is growing interest from China to get involved in security issues in the continent. To secure the exports of raw material and access to the African market, China is deploying more naval vessels along the coast so as not to be dependent on foreign security forces. China is also getting involved in the anti-piracy fight (Shinn and Brown, 2012). However, military cooperation goes back to the Cold War period when China was keen to help African liberation movements. Apart from some traditional allies such as Somalia and Uganda, China also had military ties with non-aligned countries such as Egypt. Military equipment worth \$142 million was sold to African countries between 1955 and 1977. Two decades after the collapse of the Soviet Union, military relations are now based on business interests rather than ideology (Holslag, 2009). There is no Chinese military presence in Africa other than that used in peacekeeping. In 2004, China deployed around 1,500 soldiers under the UN umbrella, dispatched between Liberia and the Democratic Republic of the Congo. China is also present via its military attachés; as of 2007, it has 14 attachés in 14 different African countries while there are 18 African countries who maintain their attachés in Beijing. Apart from peacemaking, China provides military training and equipment to a few countries, though this does not require military forces to be deployed (Foot, 2001; Holslag, 2008). Due to the low prices of Chinese-made weaponry and military equipment, an increasing number of African countries shifted their source of supply from traditional providers such as Russia to China. However, the selling of arms to some states accused by Western countries of war crimes, such as Sudan, have prompted criticism in the West (Holslag, 2009). Yet China has established a permanent military dialogue only with South Africa. The number of accredited military officers in Chinese embassies, that is, military attachés and their support staff, has barely or not expanded at all in the last few years. In fact, only in 15 countries are Chinese military attachés assigned on a permanent 
basis. China's military diplomacy in Africa remains modest, and it has not kept up with the impressive number of Chinese trade officials posted in African nations to strengthen economic ties in the last few years (Holslag, 2008). There is no evidence that China's military aid successfully counterbalances other powers, such as the United States. Apart from Sudan and Zimbabwe, most countries that have received Chinese military aid in the last few years are also supplied by Washington. In 2007, Beijing temporarily froze the supply of heavy arms to Khartoum after pressure from the West. When Nigerian government announced that it would turn to China instead of the United States for arms, Beijing's response was reluctant, and no major supply operations materialized (Holslag, 2009). China's military aid programs should not be considered as support for its forays into the mining industry. For instance, between 2004 and 2008, resource-rich Nigeria received only half as much military aid as Ghana or Uganda. During this period, China provided more military assistance to Angola than to Sudan, even though the security challenges in the latter were much greater. Although violence in Somalia has threatened China's oil exploration activities in both Ethiopia and Kenya, China only made a commitment to Kenya to help in protecting its border. China has, at times, provided military aid, but such assistance does not seem to be part of any coherent strategy related to protecting its security interests (Holslag, 2009). Yet Chinese military presence is negligible in Africa. China has no bases in Africa, as does the United States and France, nor has it trained African soldiers to counter threats to its national interests. In Sudan, Zimbabwe, Cameroon, and Gabon, China has employed teams of three to ten instructors, but they are assisting in the maintenance of equipment, rather than providing training for combat missions. In Zambia and Algeria, similar examples of cooperation exist but are limited to medical activities. Other major powers deployed naval vessels in an effort to combat piracy and to maintain the maritime supply lines surrounding Africa. During such operations, the Chinese Navy has rarely shown its flag (Changhe, 2005; Holslag, 2009). In 2000, China sent its newest Luhai-class guided missile destroyer and a supply ship to Tanzania and South Africa. A 2002 fleet composed of a guided missile destroyer, the Qingdao, and a supply ship, the Taicang, visited Egypt. These voyages were gestures of courtesy rather than a reaction to security challenges. They were limited in duration, and no actions were attempted against pirates or poachers. In December 2008, however, the Chinese government did deploy two destroyers and a replenishment ship in the Gulf of Aden to participate in the United Nations-backed mission against piracy. A mission that was only undertaken after receiving a positive signal from US Pacific Command chief Admiral Timothy Keating (Medeiros and Fravel, 2003; Holslag, 2008). Instead of dealing with security threats unilaterally, China has resorted to bandwagoning. Although in the 1980s and early 1990s, Beijing opposed attempts by the international community to intervene in African security issues, nowadays it tends to join them. Beijing is increasingly recognizing the United Nations' role in resolving the numerous conflicts and safeguarding the sovereignty of developing nations. In the 1990s, China began supporting United Nations (UN) missions designed to implement peace agreements between rivaling parties, on the condition that a well-defined and restricted mandate was included. Traditional peacekeeping operations such as those in Somalia (UNSOM I), Mozambique, Rwanda, and Sierra Leone all were supported. When the UN Security Council decided to dispatch forces to Liberia in 2003, China offered to support the mission and gradually increased the number of its peacekeepers to 1,300 in 2007. China's focus on the primacy of sovereignty, requiring at minimum the state's consent, collided with the willingness of other nations to intervene aggressively under the UN Charter's. Chapters VII mandate. Beijing loudly opposed the move by European countries to push for Operation Turquoise in Rwanda, Washington's call to broaden the UNSOM mandate, or France's demand for a troop increase in the 2004 UN operation in Ivory Coast. Despite its strong concerns, China did not veto these interventions at the UN Security Council, but rather abstained and remained aloof from implementation. Sudan was the first instance where China actively lobbied an African government to permit a UN mission on its soil (Campbell, 2008; Holslag, 2009). The fact that Beijing recognizes the importance of collective security became apparent in 2006, when China was the first nation to ask the UN Security Council for a peacekeeping mission in Somalia. In June that year, at a Security Council meeting in Addis Ababa, China's Permanent Representative to the UN, Wang Guangya, scolded other diplomats for neglecting Somalia and urged them to support the deployment of peacekeepers. In 2007, in early consultations with France, China supported a French draft resolution on Chad calling for the dispatch of mainly European peacekeepers under the auspices of Chapter VII. It was significant that China approved the "close liaising" with the Hybrid Operation in Darfur (UNAMID), where earlier it had objected to the development of links between UNAMID and UN missions (Foot, 2001; Holslag, 2008). China is also turning to African regional organizations to collaborate on security issues. In the China-Africa Action Plan, approved in November 2006, Beijing vowed "to support Africa in the areas of logistics" as well as "to continue its active participation in the peacekeeping operations and demining process in Africa and provide, within the limits of its capabilities, financial and material assistance as well as relevant training to the Peace and Security Council of the African Union." In June 2006, the Chinese government granted the African Union's Mission in Sudan \$3.5 million in budgetary support and humanitarian aid. Earlier, it provided financial and technical support to the Association for West African States (Holslag, 2009). In 2002, 
China joined the Kimberley Process, a joint government, international diamond industry, and civil initiative designed to stem the flow of conflict diamonds originating from Africa. In 2005, China allowed a voluntary peer review of its support for the Kimberly Process. Despite the strategic importance of Africa, China does not try to safeguard its foothold in the region by unilaterally projecting military power. In Africa, its military diplomacy remains limited when compared with defense initiatives in other regions. Instead of relying on a military presence to counterbalance other powers, the PRC tends to join collective security efforts within the framework of the United Nations and African regional organizations. Over the past few years, this strategy of joint ventures has evolved from passive support to active cooperation. Beijing has softened its devotion to non-interference. While maintaining the primacy of sovereignty, it has become willing to support interventions whenever regional stability is at stake (Kejin, 2005; Holslag, 2008). The PRC is going through the early stage of resecuritization of its Africa strategy, and joining with other nations in an allied strategy can be considered the easiest immediate response. Yet China has not developed sufficient means to back up its security policy with military power. This is a matter of budgetary constraints. Building an independent and sustained military presence is a costly affair and would, at present, overstretch the PLA's capabilities, while Asia remains its primary focus. The PLA does not possess the logistical capacity to support sustained region-wide deployment in Africa. Its long-range airlift and sealift, as well as its intelligence and command capabilities, are not up to the task. Also, the Chinese government wants to avoid the People's Republic being perceived as a hegemonic power (Campbell, 2008; Holslag, 2009). China's interests in Africa have changed over the past decades and will undoubtedly continue to evolve. The concept for its security policy in the region will depend on the role that Africa plays as a supplier of natural resources. Africa currently supplies approximately 30 percent of China's oil imports. Beijing and its African partners announced that they are preparing to increase bilateral trade to $\$ 100$ billion by the year 2010. Most of this increase will come from the import of raw commodities. In recent years, Chinese companies have laid the foundation for a substantial increase in the production of resource industries. Exploration in the Gulf of Guinea, Angola, and the Horn of Africa has the potential for an increase in oil exports to China of more than 80 percent in the next ten years. Chinese companies are just starting to tap the large mines that were recently acquired in Gabon, the Democratic Republic of Congo, Namibia, and elsewhere on the continent. Given the fact that other emerging markets such as India and Brazil are shifting the use of their raw materials from export to domestic consumption, the economic relevance of Africa to China cannot be overstated (Holslag, 2009).

\section{China's Quest for Africa's Natural Resources}

A quarter of China's oil imports come from Africa such as Algeria, Angola, Chad, Sudan, Nigeria, Gabon and Equatorial Guinea. The thirst for oil is becoming so important that even the 'One China Principle' is being disregarded since Chad has diplomatic relations with Taiwan. A new pipeline from Chad to Cameroon opened in 2003 so that oil from Chad can be transported directly to a major port (Ajakaiye, 2006; Hurst, 2006; Davies, et al 2008; Obiorah, 2008; Bhaumik and Yap, 2009). China not only imports oil and minerals from Africa, it also needs access to more agricultural land. With its increasing population and rapid industrialization, farmland in China has become scarce and in the future the country will have to rely on food imports to feed its own population. China is currently investing in agriculture, fisheries and related secondary production in Africa and has already signed contracts with Sierra Leone, Gabon and Namibia to allow Chinese fishermen to fish in their coastal waters. In addition, they have leased agricultural land in Zambia, Tanzania and Zimbabwe (Tull, 2006; Manji and Marks, 2007; Lee and Shalmon, 2008; Berthélemy, 2009; Kohli, 2009). By 2004, nearly 700 Chinese companies were operating in 49 African countries. Chinese state companies invest mainly in oil, mines, fishing, woods and precious metals and infrastructure and also in sectors that the West has neglected because they are less profitable. For example, China has reopened the Zambian copper mines and is looking for oil fields off the coast of Gabon. In 2004, Chinese investments in Africa accounted for more than US\$900 million. This is around $6 \%$ of total investments of US\$16 billion in Africa (Eisenman and Kurlantzick, 2006; Wang, 2007; Alden and Alves, 2009). Not surprisingly, China is investing in countries where it is getting its natural resources from. In 2004, oil-exporting countries such as Algeria, Libya, Nigeria and Sudan accounted for $54 \%$ of total Chinese investments. Zambia is also an important trade partner and China recently reopened the Chambezi Mining Company. Other countries that received a relatively large share of Chinese trade were Ethiopia and Botswana (Looy, 2006; Asche and Schüller, 2008; Butts and Brent, 2009).

\section{Sino-African Trade, Aid and Economic Cooperation}

As early as 1980, the total Sino-African trade volume was US\$1 billion. In 1999, it was US\$6.5 billion and in 2000, US $\$ 10$ 
billion. By 2005, the total Sino-African trade had reached US\$39.7 billion before it jumped to US\$55 billion in 2006, making China the second largest trading partner of Africa after the United States, which had trade worth US\$91 billion with African nations. The PRC also passed the traditional African economic partner and former colonial power France, which had trade worth US\$47 billion. In 2010, trade between Africa and China was worth US\$114 billion and in 2011, US $\$ 166.3$ billion. In the first 10 months of 2012 it was US\$163.9 billion (Snow, 1988; Taylor, 1998; Caniglia, 2011). In order to coordinate multiple features of its growing relationship with Africa, China has established the Forum on ChinaAfrica Cooperation (FOCAC). The first FOCAC conference, held in Beijing in 2000, was attended by high-level officials from over 40 African nations. Follow-up meetings were held in 2003 (Addis Ababa), 2006 (Beijing), 2009 (Sharm elSheikh, Egypt) and 2012 (Beijing). The consistency of the FOCAC conferences is beyond anything ever attempted by any Western nation, and they go beyond economics, establishing country-to-country exchanges in culture, journalism, and education (Shinn and Brown, 2012). In January 2006, China issued a white paper, "China's African Policy," in which it outlined its future orientation. After repeating the central themes of China's policy, the economic section of the white paper highlighted China's determination to step up cooperation in water, electrical power, transportation, and communication infrastructure projects development; mutual benefit and common development, to develop and exploit rationally their resources; and to "do its best to provide and gradually increase assistance to African nations with no political strings attached." The growth of trade between China and Africa was exponential in the decade from 2000 to 2010. The early years of the People's Republic, trade was not motivated by profit, but viewed as a vehicle to advance its political agenda internationally. With Egypt as its primary trading partner, China, in 1955, exported $\$ 23$ million worth of goods to Africa, with imports of $\$ 27$ million, for a total of $\$ 50$ million in trade. Ten years later, the total jumped to just under \$247 million. Most African governments welcome Chinese investments, especially following the decline in Western investment after the end of the Cold War. Chinese companies also invest in infrastructure, manufacturing, and agriculture, areas that have been avoided in recent years by private Western companies (Shinn and Brown, 2012). From 1950 to 1973 (the Phase I), China's foreign aid had kept risen up both in terms of the total amount and its proportion in GNP and the financial expenditure in the corresponding period. The total amount of foreign aid increased to 337 million RMB in 1959 from the average annual amount of 76 million RMB during the period of 1950 to 1952, which covered 0.23 $\%$ the GNP at that time and $0.62 \%$ of the financial expenditure. In 1973 , the total amount of China's foreign aid rose up to 5.584 billion RMB, which shared $2.05 \%$ of the GNP at that time and $6.9 \%$ of the financial expenditure. After 1955, the recipient of China's foreign aid has been expanded to some of the African countries (Shinn and Brown, 2012). In Phase II, both the total amount of the foreign aid and its proportions to GNP and the financial expenditure were all presenting a descending curve. These figures decreased from the total amount of 4.771 billion RMB, covering $1.71 \%$ of the GNP and $6.0 \%$ of the financial expenditure in 1974 down to 1.562 billion RMB of the total amount in foreign aid, covering $0.08 \%$ of GNP and $0.51 \%$ of the financial expenditure in 1990. During the same period, China's aid to Africa also decreased due to the same reasons. After the opening reform in 1978, China made adjustment in its diplomatic policies, and emphasized that the work on external relations should serve for the domestic modernization construction (Shinn and Brown, 2012). China's foreign aid had since 1990s entered a new period of Phase III which emphasized on reciprocity and mutual benefit, economic benefits, the integration of the political interest and the obligations of a "big country". After the ending of the Cold War, in order to comply with the global trend, China has made reforms on its foreign aid, and increased the amount of the aid fund and expanded the coverage of recipient countries, it also made adjustments in concrete forms of its aid. During the period of 1991 to 2005, China's foreign aid expenditure had been soaring up. Its rose from 1.68 billion $\mathrm{RMB}$, with the proportion of $0.08 \%$ in GNP and $0.50 \%$ in financial expenditure in 1999 up to 7.47 billion RMB, with the proportion of $0.04 \%$ and $0.22 \%$ in GNP and financial expenditure respectively. And China had chosen Africa as the main recipient area of its foreign aid. Since the past 50 years, China's foreign aid to Africa has amounted to 44.4 billion RMB covering $30 \%$ of the total amount of 120.773 billion RMB. These foreign aids to Africa have sponsored about 900 infrastructure and social development projects (Shinn and Brown, 2012). Chinese construction of infrastructure in Africa is led by state-owned enterprises (SOEs). Chinese companies, with favorable loans from state-owned banks and government funding agencies, and often using Chinese workers, are profitable, but they are not seeking super-profits. Only a shrinking minority of the loans from China involves the bartering of resources. What makes these deals even sweeter is that African countries sometimes pay the SOEs with concessional loans from China, which can offer a 2-3\% interest rate, with 15-20 years to pay them off, and a 5-7 year grace period. In 2007, the Chinese Export-Import Bank provided $\$ 24$ billion in loans, with approximately $\$ 8-9$ billion in concessional loans. Some of China's loans have been written off entirely, and, despite the fact that China's loans to Africa have now risen to multi-billions in dollar value, they are still minor compared to the almost $\$ 300$ billion Africa owes to Western countries and financial institutions, with no lasting physical return (Shinn and Brown, 2012). For example, the volume of trade between Nigeria and China continued 
to grow at low levels until rapid growth turned China in 1993 from a net exporter of crude oil to the second-largest importer of crude oil in the world. Gulf of Guinea countries like Nigeria, which produce sweet, low-sulfur crude and offered developing markets open to international investment, were particularly attractive to the Chinese. As China secured various joint-venture contracts with Nigerian oil companies, often in exchange for low-interest loans and targeted development projects, the volume of trade rapidly increased from 1.3 billion Naira in 1990 to 5.3 billion in 1996 to 8.6 billion. Most of this growth was attributable to the oil sector, with a small fraction emanating from the importation of cheaply manufactured Chinese goods and products (Shinn and Brown, 2012). Nonetheless, many imported Chinese goods were often substandard, leading the Standards Organization of Nigeria in October 1996 to threaten China that a formal complaint would be lodged with the World Trade Organization if the situation was not immediately corrected. The Chinese responded by explaining that they had not deliberately engaged in the dumping of inferior goods in Nigeria and that it was often Nigerian businessmen of dubious disposition who were ordering products of questionable quality (Shinn and Brown, 2012). The acquisition of a stake in Standard Chartered Bank, one of Africa's leading banks, as well as a stake in IBTC-Chartered Bank in Nigeria, by one of China's largest banks, has significantly raised China's investment profile. As Chinese banks continue to support Chinese enterprise in Nigeria, a surge in the level of business involvement is expected to grow sharply (Shinn and Brown, 2012).

During the year 2011, trade between Africa and China increased a staggering 33\% from the previous year to US $\$ 166$ billion. This included Chinese imports from Africa equalling US \$93 billion, consisting largely of mineral ores, petroleum, and agricultural products and Chinese exports to Africa totaling $\$ 93$ billion, consisting largely of manufactured goods. Outlining the rapidly expanding trade between the African continent and China, trade between these two areas of the world increased further by over 22\% year-over-year to US $\$ 80.5$ billion during the first five months of the year 2012 . Imports from Africa were up $25.5 \%$ to $\$ 49.6$ billion during these first five months of 2012 and exports of Chinese-made products, such as machinery, electrical and consumer goods and clothing/footwear increased $17.5 \%$ to reach $\$ 30.9$ billion. China remained Africa's largest trading partner during 2011 for the fourth consecutive year (starting in 2008). To put the entire trade between China and Africa into perspective, during the early 1960s trade between these two large parts of the world were in the mere hundreds of millions of dollars back then. Europe dominated African trade during these formative years of European decolonization process in the African continent. Even as early as the 1980s, trade between China and Africa was minuscule. Trade between China and Africa largely grew exponentially following China's joining of the World Trade Organization (WTO) and the opening up of China to emigration (of Chinese people to Africa) and the free movement of companies, peoples, and products both to and from the African continent starting from the early 2000 onwards (Caniglia, 2011). One third of Chinese oil imports come from Africa. China also gets a significant amount of raw materials such as minerals so that since 2000, exports to China increased eleven times over. The access to raw material also helps the Chinese Communist Party (CCP) to remain in power and strengthen its position. China needs to export to new markets to sustain its industrial production. Since 2000, exports to Africa have increase nine times. It only accounts for $4 \%$ of global trade, but remains an important number while looking at the rise in a short period of time (Shinn and Brown, 2012). More specifically, one-third of China's oil supplies come from the African continent, mainly from Angola. Investments of Chinese companies in the energy sector have reached high levels in recent years. In some cases, like in Nigeria and Angola, oil and gas exploration and production deals reached more than $\$ 2$ billion. Many of those investments are mixed packages of aid and loan in exchange for infrastructure building and trade deals (Muekalia, 2004). In agriculture, Benin and the Sahel countries of Burkina Faso and Mali supply up to 20\% of China's cotton needs. While Côte d'Ivoire supplies China with cocoa, large shipments of coffee are imported from Kenya. As for fish products, Namibia remains one of the main providers (Muekalia, 2004; Taylor, 2006; Alden, 2007). China's trade with Africa is highly concentrated. About $60 \%$ of Chinese exports are destined for only six countries: South Africa (21\%) Egypt (12\%), Nigeria (10\%), Algeria (7\%), Morocco (6\%) and Benin (5\%), while over 70\% of Chinese imports originate from four countries of Chinese imports originate from four countries: Angola (34\%), South Africa (20\%), Sudan (11\%) and Republic of Congo (8\%). The high country concentration of China's imports in part reflects the importance of crude oil $(70 \%$ of imports from Africa) which accounts for almost all of China's imports from Angola and Sudan. China's agricultural imports have a modest share, although they constitute the bulk of imports from several African countries. African imports from China are somewhat more diversified, although machinery and transport equipment, manufactured goods and handicrafts account for the bulk of imports (Berthelemy, 2011; Renard, 2011; Schiere and Rugamba, 2011).

\section{Chinese Investment and Infrastructural Development in Africa}

Perhaps, one noticeable shortcoming of China's engagement in Africa has been its failure to undertake regional and 
continental transformative infrastructure projects in water, energy, and rail transportation, which would result in a quantum leap in advancing the economic productivity of every nation, enabling African countries to eliminate abject poverty and adequately provide for the general welfare of their citizens (Shinn and Eisenman, 2012). But China's contribution has been impressive. According to my back-of-the-envelope estimate from figures provided by the World Bank, itemized in this book, between 2001 and 2007, China's estimated financial commitments to infrastructure projects in Africa totaled about $\$ 16$ billion. In these years, 33\% of the projects were for the production of power (particularly hydroelectric) with China committed to building 17 dams in 19 countries; another 33\% were for roads and railroads; and 17\% went to the information and telecommunication sector. China is building real physical wealth. One key example is the TanzaniaZambia railway, the first major infrastructure project that China completed on the continent, in 1975. China picked up the project, with a \$401 million long-term, interest-free loan in 1970, after the World Bank refused to fund the project, arguing that it would not be economically viable. This pattern has continued. In 2007, China's ExIm Bank provided the Democratic Republic of Congo with a $\$ 6.5$ billion loan (reduced from the original $\$ 9$ billion, due to intimidation from the IMF and Western financial interests) to fund the construction 2,000 miles of rail, health centers, universities, and 5,000 housing units. Like other deals, this one involves Chinese companies and involves repayment in resources, the DRC's copper, cobalt, and gold (Shinn and Eisenman, 2012). In 2009, China and Ethiopia agreed to a \$1.9 billion deal for the construction of two hydro-electric dams. An additional multi-billion-dollar loan was issued in 2010, which will help fund a light rail line in Ethiopia's capital, Addis Ababa, and a new rail link from the capital to the Republic of Djibouti. China's Export-Import Bank, in 2007, financed the construction of the Mpanda Nkua Dam in Mozambique with a loan of \$2.3 billion, which also covered the funding of a transmission line to provide the capital, Maputo, with electrical power. In 2010, China announced that it intended to invest an additional $\$ 13$ billion over the next five years for industrial, mining, tourism, and energy projects (Shinn and Eisenman, 2012).In 2010, the ExIm Bank signed a 20-year \$10.4 billion concessionary loan for infrastructure projects in Ghana to include almost $\$ 3$ billion for roads and $\$ 6$ billion for railway construction. The China Development Bank offered another $\$ 3$ billion to help develop a new oil and gas sector. Another American expert on China-Africa relations estimates that China has financial contracts for infrastructure projects in Africa totaling about \$40 billion annually (Shinn and Eisenman, 2012). For instance, despite various challenges, the Sino-Nigerian relationship continued to expand as a wide array of development projects were contracted to the Chinese. The relationship expanded significantly during the presidency of Olusegun Obasanjo. One major project undertaken was the Abuja All-Africa Games village that was contracted to the China Civil Engineering Construction Corporation (CCECC) in 2000 to build some 5,000 housing units for international athletes participating in the eight annual All-Africa Games (Shinn and Eisenman, 2012). The construction of the village provided an opportunity for the Chinese to showcase their increasing cooperation with Africa in a high-profile international setting. Today, such large-scale, public infrastructure projects being undertaken by Chinese contractors are being referred to as "prestige projects." The launching of the Forum on China-Africa Cooperation (FOCAC) - a programme designed to boost economic and social development for Africa that consisted of three highprofile ministerial meetings between 2000 and 2006 - further cemented the China-Africa relationship, leading to a particularly important role for Nigeria. By 2006 the tone of the Chinese had changed, and President Hu Jintao and Prime Minister Wen Jiabao of China were participating in regular shuttles to Africa, with Nigeria as a major port of call (Shinn and Eisenman, 2012). Notwithstanding its interest in Nigeria's petroleum sector, China's development assistance also attempts to strengthen infrastructure and revive the agricultural sector. In agriculture, a tripartite agreement involving China, Nigeria, and the Food and Agricultural Organization (FAO), pledged the deployment of 500 Chinese experts to help with food production and water conservancy in arid regions of the country. Already, 400 of the 500 pledged experts are hard at work in Nigeria. In addition to the development of the agricultural sector, several protocols and agreements in the last few years have resulted in several Chinese companies, from both the public and private sectors, becoming active in rehabilitation and expansion in such areas as electricity, road and rail transportation, and telecommunications. The companies that have entered the Nigerian market to work on these important initiatives include ZTE Company, AlcatelShangai-Bell, and China Putian (Shinn and Eisenman, 2012). There are an estimated 800 Chinese corporations doing business in Africa, most of which are private companies investing in the infrastructure, energy and banking sectors. Unconditional and low-rate credit lines (rates at $1.5 \%$ over 15 years to 20 years) have taken the place of the more restricted and conditional Western loans. Since 2000, more than $\$ 10 \mathrm{bn}$ in debt owed by African nations to the PRC has been canceled. Even though Africa has gained from commodity exports to China, Chinese exports to Africa as well as Chinese business practices isn't helping so much, says Mohamed Gueye (Alden, 2007). China Development Bank (CDB), also established in 1994, provides loans to Chineseifirms and has launched China-Africa Development Fund to support Chinese FDI in Africa. China Export and Credit Insurance Corporation (SINOSURE) has since 2001 provided insurance against the risks involved in Chinese exports and foreign investment. China's presence in Africa also involves a 
broad range of private sector actors including multinationals, small businesses, traders, governments which at times act directly, mainly through the state-owned firms (Renard, 2011). China's FDI in Africa is closely linked to trade and development assistance. Thus FDI has increased over the past decade in tandem with increased Sino-African trade, although China's FDI to Africa remains marginal in terms of China's total outward FDI flows $(0.2 \%$ in 1991 and $5.9 \%$ in 2007). According to Ministry of Commerce China'ss FDI in Africa has increased by $46 \%$ per year over the past decade. The stock of foreign investment stood at $\$ 4.46$ billion in 2007 compared to \$56 million in 1996 (Schiere and Rugamba, 2011).

During the first of 2009 , Chinese FDI flows into Africa increased by $81 \%$ compared to the Period in 2008, reaching over $\$ 0.5$ billion. Similarly, China's outward FDI to Africa is dominated by a few resource-rich countries. From 2003-2007, over half of Chinese FDI flows into Africa were absorbed by three countries: Nigeria (20.2\%), South Africa (19.8\%) and Sudan (12.3\%). Algeria (oil) and Zambia (minerals) came 4th and 5th, respectively. Chinese FDI to Nigeria is set rise, because China National,Offshore Oil Company (CNOOC), a state-owned enterprise and one of the three major energy players in China, is negotiating the acquisition ofrights to 1/6th of Nigeria's oil reserves (Renard, 2011).

\section{Sino-African Diplomatic Relations}

In the post colonial period, China sought to extend its influence in other developing countries and export the communist revolution. The newly independent countries look to China as an alternative to domination by the former colonial powers. For example, China signed an economic and technical agreement with Guinea in 1960, a year after independence; subsequently provided an interest-free loan of $\$ 20$ million to Ghana (the first African country to establish diplomatic relations with China); and recognized Mali upon independence and sent a trade mission the following year. However, China also established relationships with other countries, for example in North Africa, with Algeria, Morocco and Tunisia (Medeiros and Fravel, 2003; Berthelemy, 2011). China signed economic and technical cooperation agreement with Algeria and granted it a $\$ 50$ million loan in 1950s. Sino-African relations were maintained in the 1960s, and China was present at various Afro-Asian Conferences held in Africa. China gave priority to highly-visible, prestige projects such as stadia and hospitals. China also financed construction of a railway line between Zambia and Tanzania between 1973 and 1976, and dispatched 15,000 Chinese for the project, although this investment was earlier turned down by the British Government and the World Bank (Renard, 2011; Schiere and Rugamba, 2011).1Chinese diplomacy in Africa is carried out by the Ministries of Foreign Affairs and Trade, has focused on bilateral relationships with African governments. In addition, several state-owned banks backed China's presence in Africa. Exim Bank (China Export-Import Bank) was established in 1994 to promote Chinese exports and foreign direct investment (FDI) specifically in the infrastructure sector: roads, power plants, pipelines, telecommunications, etc. This bank has a less risk-sensitive profile compared to private banks, but is more willing to support investment projects than Western counterparts (Berthelemy, 2011; Schiere and Rugamba, 2011). China has been engaged in a kind of "health diplomacy" towards Africa since the 1960s. Health care development and medical assistance have been one of the main successful areas of cooperation. Between the early 1960s and 2005, more than 15,000 Chinese doctors have been sent to Africa to help treat different cases in more than 47 countries. The medical teams, known as yiliaodui, have treated more than 170 million patients during the same period. In September of 2007, China promised the Democratic Republic of the Congo to build 31 hospital units and other 145 smaller health care centers, a project due to be completed in March 2010 (Taylor, 2009).

\section{Conclusion}

We have so far examined Chinese incursion or penetration into Africa in the recent times. We also noted that contrary to the believe that Chinese presence in Africa is recent, China's contact with Africa has in fact spanned several centuries perhaps as far back as 14th century. The difference was that the contact had no imperialistic motive like that of European penetration and perhaps that of Arabian incursion. Such practice has continued to define Chinese relations with African countries even in the present times, that is, the policy of non-interference in the internal affairs of African states or to respect the sovereignty of African states. The era of Chinese (Cultural) Revolution under Mao Tse Tung was characterized by policy of wooing African countries like Ghana, Angola, among others towards Chinese brand of communist ideology, isolate Taiwan and Soviet Union, abolish two-China policy and to secure China's recognition and readmission into the United Nations (UN), and more importantly, into United Nations Security Council (UNSC) permanent seat hitherto occupied by Taiwan. All these it achieved through soliciting for African supports. The post-Mao China under Deng Tsiao Ping and even beyond was indeed a period characterized by opening up with the attendant massive growth 
in Chinese economy. This era heralded the renewed interest in Africa by China described as era of the new scramble for Africa in areas like trade, investment, diplomacy, foreign policy, economy, agriculture, education, health, transport, infrastructure, tourism, security, defence, military, oil and gas. We demonstrated that Chinese new interest in Africa was primarily in area of securing strategic and important natural resources like crude oil. Not surprisingly, impact of Chinese incursion into Africa has not improved Africa's economy significantly.

\section{References}

Ajakaiye, O. (2006) "China and Africa: Opportunities and Challenges" A Paper Presented at the African Union Task Force on Strategic Partnership between Africa and the Emerging Countries of the South in Addis Ababa, Ethiopia on September 11-13.

Alden, C. (2007) China in Africa: Partner, Competitor or Hegemon? London: Zed Books.

Alden, C. and Alves, A. (2009) "China and Africa's Natural Resources: The Challenges and Implications for Development and Governance", South African Institute of International Affairs (SAIIA) Occasional Paper No. 41.

Asche, H. and Schüller, M. (2008) China's Engagement in Africa: Opportunities and Risks for Development, African Department, Economic Affairs.

Berthélemy, J-C. (2009) "Impact of China's Engagement on the Sectoral Allocation of Resources and Aid Effectiveness in Africa, A Paper Prepared for African Economic Conference 2009, titled: Fostering Development in an Era of Financial and Economic Crises, United Nations Economic Commission for Africa (UNECA), November 11-13, 2009, Addis Ababa, Ethiopia.

Berthelemy, J.C. (2011) "China's engagement and aid effectiveness in Africa", in R. Schiere, L. Ndikumana and P. Walkenhorst (eds) China and Africa: An Emerging Partnership for Development? Tunis: African Development Bank Group.

Bhaumik, S. K. and Yap, C.C. (2009) "Chinese State's Economic Cooperation-Related Investment: An Investigation of its Direction and Some Implications for Outward Investment", William Davidson Institute Working Paper No. 966.

Butts, K.H. and Brent, B. (2009) "China's Pursuit of Africa's Natural Resources", Collins Centre Study 1-09.

Campbell, H. (2008) "China in Africa: Challenging US Global Hegemony," Third World Quarterly, 29: 89-105.

Caniglia, L. (2011) "Western Ostracism and China's Presence in Africa", China Information 25 (2).

Changhe, S. (2005) "Discovering China's New Diplomacy: Multilateral International Institutions and New Thought of China's Diplomacy," World Economics and Politics, April 4.

Davies, M. et al (2008) How China Delivers Development Assistance to Africa, Stellenbosch: Centre for Chinese Studies (CCS).

Eisenman, J. and Kurlantzick, J. (2006) "China's Africa Strategy" Current History May.

Foot, R. (2001) "Chinese Power and the Idea of a Responsible State," The China Journal, 45: 1-19.

Holslag, J. (2008) "China's Diplomatic Maneuvering on the Question of Darfur," Journal of Contemporary China, 17.

Holslag, J. (2009) "China's New Security Strategy for Africa", Parameters.

Hurst, C. (2006) "China's Oil Rush in Africa", Energy Security July.

Kejin, Z. (2005) "Hard Diplomacy, Soft Landing: On the Formation and Consequences of the New Thought of China's Diplomacy," International Review.

Kohli, J.S. (2009) "The Dragon on Safari: China's Africa Policy", IPCS Special Report, 86.

Large, D. (2007) "China's Return to Africa", in F. Manji, and S. Marks (eds), African Perspectives on China in Africa, Nairobi: Fahamu.

Lee, H. and Shalmon, D. (2008) "Searching for Oil: China's Oil Strategy in Africa", in R.I. Rotberg (ed) China into Africa: Trade, Aid and Influence, Massachusetts: World Peace Foundation.

Looy, J. (2006) "Africa and China: A Strategic Partnership?" ASC Working Paper, 67.

Manji, F. and Marks, S. (eds) (2007) African Perspectives on China in Africa, Nairobi: Fahamu.

Medeiros, E.S. and Fravel, M.T. (2003) "China's New Diplomacy," Foreign Affairs, 82: 21-35.

Muekalia, D.J. (2004) "Africa and China's Strategic Partnership", African Security Review 13 (1): 5-11.

Obiorah, N. (2008) "Rise and Rights in China-Africa Relations", SAIS Working Papers in African Studies 03-08.

Renard, M-F. (2011) "China's trade and FDI in Africa", in R. Schiere, L. Ndikumana and P. Walkenhorst (eds) China and Africa: An Emerging Partnership for Development? Tunis: African Development Bank Group.

Schiere, R. and Rugamba, A. (2011) "Chinese Infrastructure Investments and African integration", in R. Schiere, L. Ndikumana and P. Walkenhorst (eds) China and Africa: An Emerging Partnership for Development? Tunis: African Development Bank Group.

Shinn, D. and Brown, K. (2012) China and Africa: A Century of Engagement, London: Chatham House.

Shinn, D. and Eisenman, J. (2012) China and Africa: A Century of Engagement, Philadelphia: University of Pennsylvania Press.

Sidoli,G. (2009) "The Role of China in Africa: An Agent for Developmental Transformation or Just Neo-Colonial Exploitation?" Defence Academy Yearbook.

Snow, P. (1988) The Star Raft: China's Encounter with Africa, New York: Weidenfeld and Nicholson.

Taylor, I. (1998) "China's Foreign Policy Towards Africa in the 1990s", Journal of Modern African Studies 36 (3): 443-460.

Taylor, I. (2006) China and Africa: Engagement and Compromise, London: Routledge.

Taylor, I. (2009) China's New Role in Africa, Boulder: Zed Books.

Tull, D.M. (2006) "China's Engagement in Africa: Scope, Significance and Consequences", Journal of Modern African Studies, 44 (3): $459-479$

Wang, J-Y. (2007) "What drives China's growing role in Africa?", IMF Working Paper No. 07/211 
